\title{
Article \\ Comparative Taxonomic Study of Launaea Cass. (Asteraceae, Cichorioideae) in Egypt
}

\author{
Ream I. Marzouk, Salama M. El-Darier, Sania A. Kamal and Iman H. Nour *
}

check for updates

Citation: Marzouk, R.I.; El-Darier, S.M.; Kamal, S.A.; Nour, I.H. Comparative Taxonomic Study of Launaea Cass. (Asteraceae, Cichorioideae) in Egypt. Taxonomy 2021, 1, 192-209. https://doi.org/ 10.3390/taxonomy1030014

Academic Editor: Adriano Stinca

Received: 7 June 2021

Accepted: 7 July 2021

Published: 12 July 2021

Publisher's Note: MDPI stays neutral with regard to jurisdictional claims in published maps and institutional affiliations.

Copyright: (c) 2021 by the authors. Licensee MDPI, Basel, Switzerland. This article is an open access article distributed under the terms and conditions of the Creative Commons Attribution (CC BY) license (https:// creativecommons.org/licenses/by/ $4.0 /)$.
Botany and Microbiology Department, Faculty of Science, Alexandria University, Alexandria 21511, Egypt; Reammarzouk@yahoo.com (R.I.M.); Salama_Eldarier@yahoo.com (S.M.E.-D.); drsaniakamal@gmail.com (S.A.K.)

* Correspondence: Iman.nour@alexu.edu.eg; Tel.: +20-1227854391

\begin{abstract}
Launaea is a polymorphic genus with inter- and intraspecific inconsistencies. The study aimed to revise the classification and identification of Launaea species in Egypt. The study also aimed to assess the inter- and intraspecific variation among taxa using macro- and micromorphological characters. Numerical analysis was carried out on 156 specimens, which were collected from 63 sites in Egypt. The results revealed that L. arabica, L. capitata, L. intybacea and L. spinosa were significantly ( $p$-value $<2.2 \times 10^{-16^{* * *}}$ ) discriminated from the other species at a high dissimilarity level. Launaea acanthodes was correctly identified as Lactuca orientalis. The study supported the inclusion of L. intybacea, L. massauensis and L. nudicaulis within section Microrhynchus, the separation of L. angustifolia and L. arabica in two distinct species. Two biotypes of L. nudicaulis were morphologically differentiated. Launaea fragilis subsp. fragilis showed considerable plasticity and variability in various characters; therefore, L. tenuiloba was considered to be merely an ecotype of L. fragilis. Launaea mucronata comprises two subspecies; cassiniana and mucronata, differentiated by their pappus type, conspicuous secondary ribs of the inner achenes, and the number of spines on the polar area of pollen grains.
\end{abstract}

Keywords: achenes; asteraceae; Launaea; morphology; pollen grains; SEM

\section{Introduction}

Asteraceae Martynov is the largest and most diverse family in the Eudicots, with 13 subfamilies and 45 tribes. The family consists of about 1600-1700 genera and 25,000-33,000 species [1]. Currently, Susanna et al. [2] recognized 16 subfamilies and 50 tribes. According to APG IV [3], the family was classified into Eudicots, Superasterids, Asterids, Campanulids and Asterales. In Egypt, the Asteraceae is represented by 98 genera, and 234 species are classified into two subfamilies; Liguliflorae and Tubiliflorae. The former is exemplified by two tribes: Cichorieae Lam. and DC, and Scorzonerinae. The Cichorieae contains six subtribes; Crepidinae Cass. ex Dumort., Hypochaeridinae Less., Hyoseridinae Less., Lactucinae (Cass.) Cass. ex Dumort., Rhagadiolinae Benth. and Hook.f. and Scolyminae Less. Lactuca L., Launaea Cass., Reichardia Roth and Sonchus L. are grouped in the subtribe Lactucinae $[4,5]$.

Launaea is a polymorphic genus with inter- and intraspecific inconsistencies, especially within section Zollikoferia DC. It comprises about 54 species and 10 subspecies and is classified into eight sections. The genus is distributed into different geographical regions, particularly Saharo-Arabian, Irano-Taranian and Sudanian S Mediterranean, Africa and SW Asia [6,7]. Most species have economic, ecological, and ethnobotanical importance such as anti-inflammatory, antioxidant, anticancer, children fever, soporific, lactagogue, diuretic, insecticidal, antibacterial and antiparasitic [8-12]. The genus displays considerable diversity in the Mediterranean and Nile regions of Egypt. According to the Egyptian flora, Boulos [5] has recorded ten taxa (9 species and 3 subspecies) and classified them into four sections: Acanthosonchus Shultz Bip., Launaea Cass., Microrhynchus Less. and Zollikoferia [5]. 
The genus was subjected to various taxonomic demarcations and allocations of its species in Egypt, which have been summarized in the Supplementary Materials (Table S1).

The current study aimed to review the classification and identification of Launaea species based on an extensive array of macro- and micromorphological characters. The study also aimed to assess the inter- and intraspecific variation among taxa.

\section{Materials and Methods}

\subsection{Collection of Specimens}

The study was constructed on 156 fresh and herbarium specimens collected from 63 sites to cover the most dominant habitats within the range of the genus distribution in Egypt (Table S2 and Figure S1). The freshly collected samples were deposited as voucher specimens at Alexandria University Herbarium (ALEX) and identified according to Kilian [7] and Boulos [5]. The herbarium specimens were loaned from Assiut University (ASTU), the Cairo Agricultural Research Center (CAIM), Cairo University (CAI) and the National Research Centre (CAIRC). Herbarium acronyms follow The Index Herbariorum [13]. The studied specimens represent 10 taxa of Launaea (L. angustifolia subsp. angustifolia (Desf.) Kuntze, L. angustifolia subsp. arabica (Boiss.) N. Kilian, L. capitata (Spreng.) Dandy, L. fragilis subsp. fragilis (Asso) Pau, L. intybacea (Jacq.) Beauverd, L. massauensis (Fres.) Chiov., L. mucronata subsp. cassiniana (Jaub. and Spach) N. Kilian, L. mucronata subsp. mucronata (Forssk.) Muschl., L. nudicaulis (L.) Hook.f. and L. spinosa Sch.Bip.). Reichardia and Launaea are the most closely related genera within subtribe Hyoseridinae [14]. As a result, the widely distributed $R$. tingitana (L.) Pau was used as an outgroup in the cluster analysis. Photographs of the whole plant materials were illustrated in the Supplementary Materials (Figures S2-S13).

\subsection{Macromorphological Characters and Numerical Analysis}

For the vegetative and floral attributes, three replicas were measured for each specimen. Specimens were examined using Olympus stereomicroscope and measured using ImageJ (1.51J8) [15]. All leaf characters were studied for the rosette leaves, except the leaf attachment and the auricle margin were studied in the cauline leaves. For the achene macromorphology, measurements were carried out on nine replicas for each specimen. The studied achenes were selected from three different positions in the fruiting capitulum, marginal, submarginal and inner, to investigate the achenes variation. The submarginal achenes represented a transition state between the marginal and the inner ones; therefore, their measurements were omitted. The achenes measurements were conducted using Olympus stereomicroscope supported with $1 \mathrm{~cm}$ ocular micrometer. The terminology of macromorphological characters follows De Vogel [16] Kilian [7], Simpson [17] and Roque et al. [18].

One hundred and fifty-six specimens were subjected to numerical analysis by using 82 macromorphological characters; 16 vegetative, 37 floral and 29 achene characters. The complete list of the assessed quantitative and qualitative macromorphological characters and their states is presented in the Supplementary Materials (Table S3). The agglomerative cluster analysis was performed through the PAST program for mixed data set [19]. The dendrogram was constructed by the UPGMA method of sorting based on the Manhattan dissimilarity coefficient.

\subsection{Micromorphological Characters (SEM) and Numerical Analysis}

The achene and pollen micromorphological characters were investigated for 17 samples obtained from 17 hypothetical groups. These individuals were selected based on the cluster analysis resulting from the study of 82 macromorphological characters performed to assess the inter- and intraspecific variation among taxa. Marginal and inner achenes were preliminarily examined using a stereomicroscope to ensure that they were of normal size, shape and maturity. The achenes were mounted directly on stubs using double-sided adhesive tape and then coated with gold, up to a thickness of $400 \mathrm{~A}$ in a sputter-coating 
unit (JFC-1100 E). The samples were examined and photographed with a JEOL JSM-5300 scanning electron microscope. A total of 11 micromorphological attributes were assessed. The terminology follows Barthlott [20], Simpson [17], Zhang et al. [21] and Hussein and Eldemerdash [22].

The pollen grains were mounted directly on a glass cover and coated with gold up to a thickness of $400 \mathrm{~A}$ in a sputter-coating unit (JFC-1100 E). An average of ten pollen grains were examined and photographed for each specimen with a JEOL JSM-5300 scanning electron microscope. The number of spines on the polar area (excluding ridges), the ratio of polar area to pollen area and the apocolpium index were investigated. The latter was calculated according to the following equation: Apocolpium index = (apocolpium diameter/equatorial diameter $\times 100$. Fifteen morphological characters were evaluated according to Punt et al. [23] terminology. The complete list of the assessed quantitative and qualitative micromorphological characters and their states were presented in the Supplementary Materials (Table S4).

The cluster analysis was achieved based on 26 micromorphological characters. The similarity among specimens was determined through the Hamming dissimilarity coefficient, and the dendrogram was constructed by the UPGMA method of sorting by using the PAST program of Hammer et al. [19]. Also, a Principal Coordinate Analysis (PCoA) was conducted to visualize similarities and dissimilarities among the 17 groups. The PCoA was performed by using the R- software (Vienna, Austria), with the required packages installed [24].

\section{Results}

\subsection{Numerical Analysis of Macromorphological Characters}

Eighty-two macromorphological characters were studied for 156 specimens; 18 vegetative and 37 floral traits (Figure 1), and 29 achenes macromorphological traits (Figures 2 and 3). The performed numerical analysis was illustrated in Figure 4.

Reichardia tingitana was segregated at the highest dissimilarity level (1.420), whereas the taxa of Launaea were divided into four groups representing the four corresponding sections: Zollikoferia at 1.253, Acanthosonchus at 1.134, and both Launaea and Microrhynchus at 1.013. A total of 17 hypothetical groups were proposed: R. tingitana, Acanthosonchus (L. spinosa), Launaea (L. capitata), four groups in Microrhynchus (L. intybacea, L. massauensis and two forms of L. nudicaulis) and ten groups within Zollikoferia (L. angustifolia subsp. angustifolia, L. angustifolia subsp. arabica, L. mucronata subsp. mucronata, L. mucronata subsp. cassiniana and six forms of L. fragilis subsp. fragilis). The morphological distinction between these groups is summarized in the Supplementary Materials (Table S5).

(a)

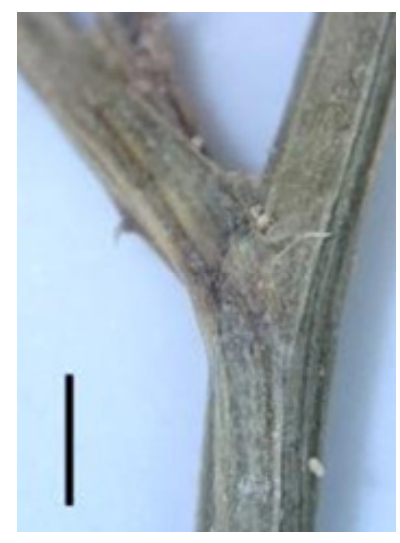

(b)

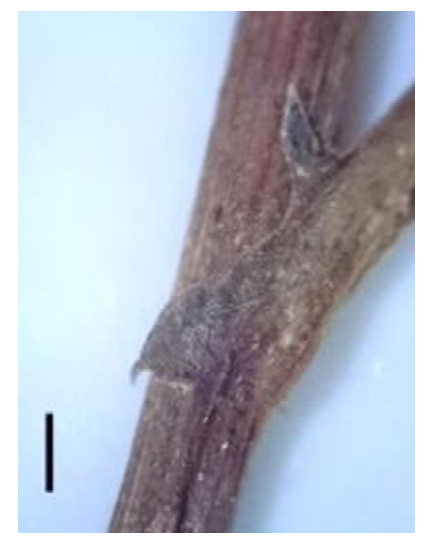

(c)

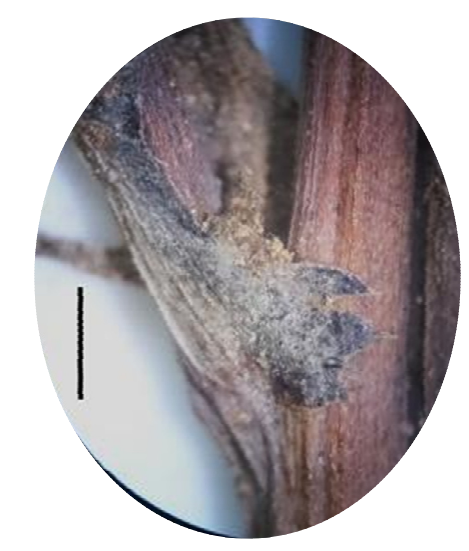

Figure 1. Cont. 
(d)

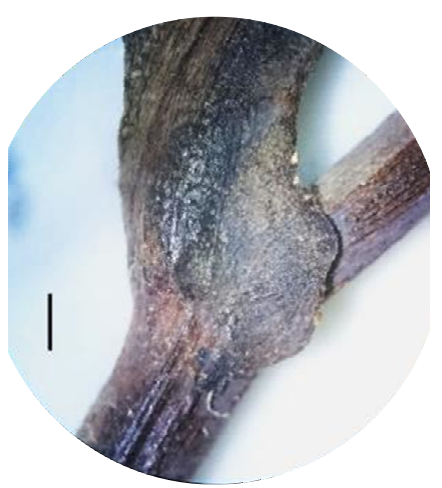

(g)

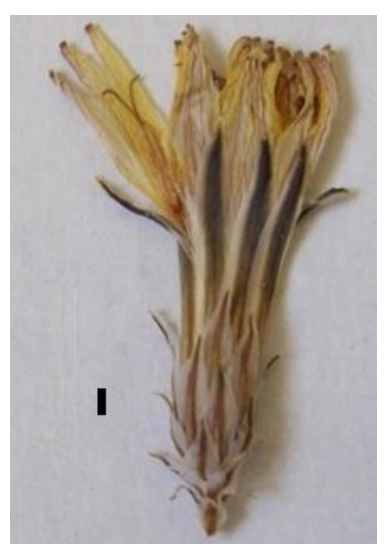

(e)

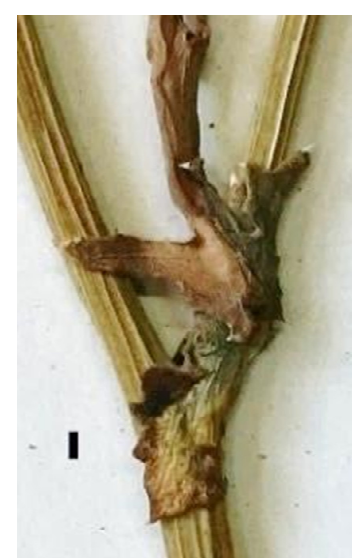

(h)

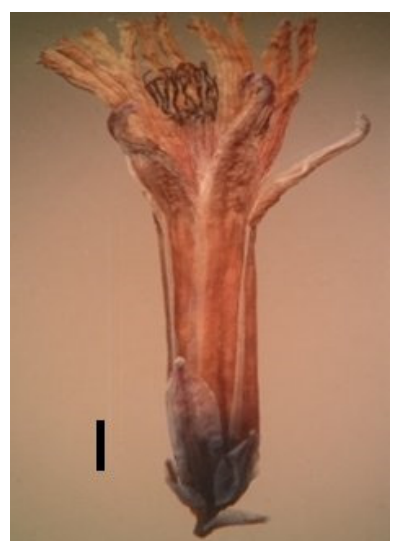

(f)

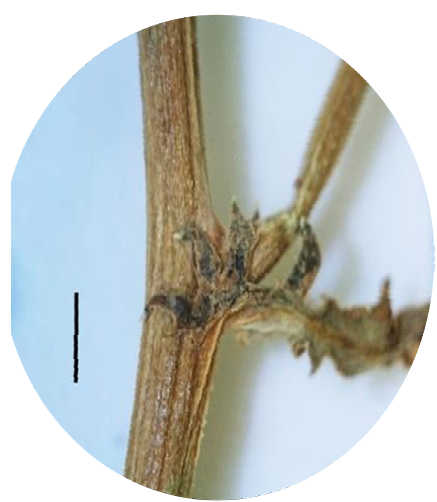

(i)

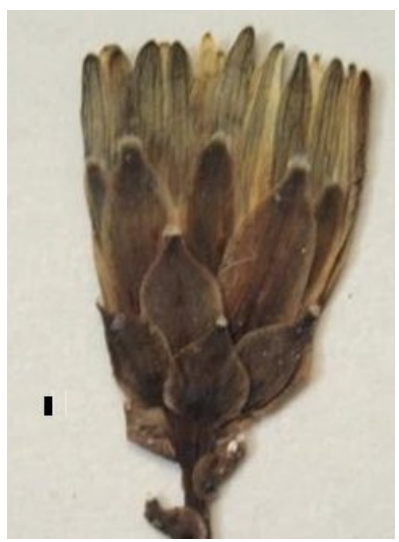

Figure 1. Stereomicrographs of Launaea leaves and capitula. (a-f) Leaf attachment and auricle margin; (a) Non-auriculated leaf in L. nudicaulis; $(\mathbf{b}, \mathbf{c})$ auriculated with semi-amplexicaul base in L. fragilis subsp. fragilis; $(\mathbf{b})$ entire margin or (c) dentate margin; (d-f) auriculated with amplexicaul base; (d) entire margin in L. fragilis subsp. fragilis or (e) dentate margin in L. fragilis subsp. fragilis or (f) dissected margin in L. mucronata subsp. cassiniana. (g-i) Capitulum shape, involucre scale graduality and ligule color; (g) ellipsoid, non-gradual and yellow ligule; (h) lanceoloid, non-gradual and yellow ligule; (i) obovoid, gradual and yellow ligule with green abaxial surface. Scale bar $=1 \mathrm{~mm}$.

(a)
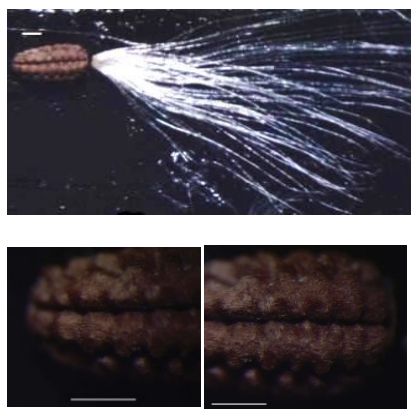

(d)
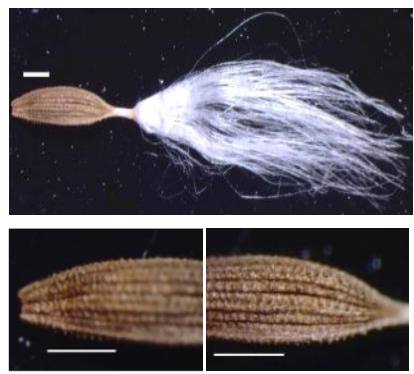

(b)
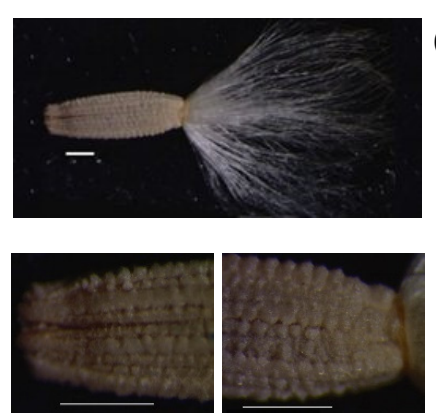

(e)
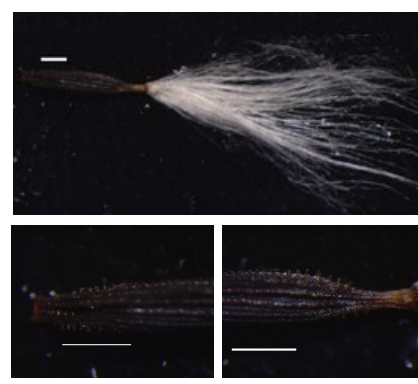

(c)
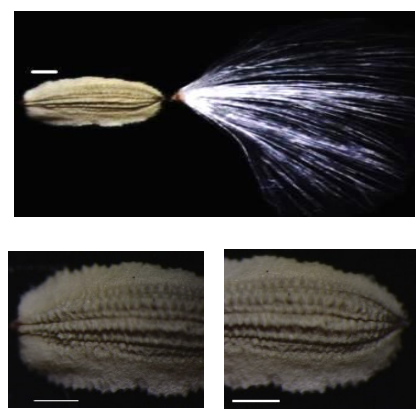

(f)
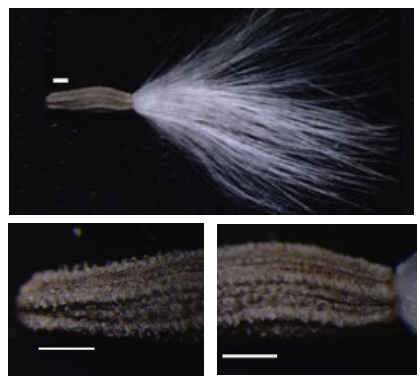

Figure 2. Cont. 
(g)
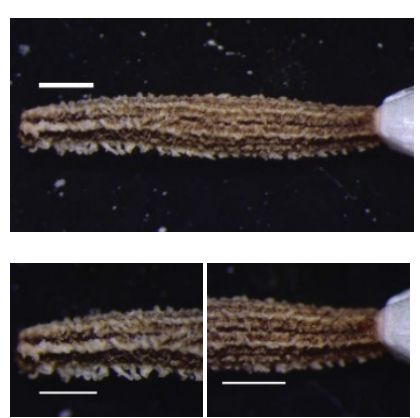

(j)
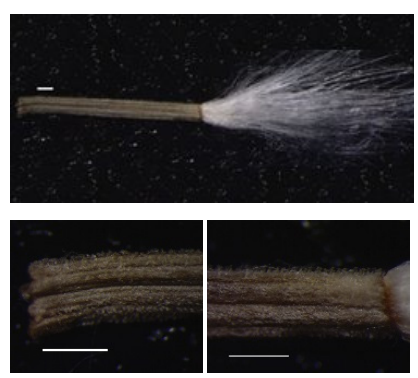

(m)
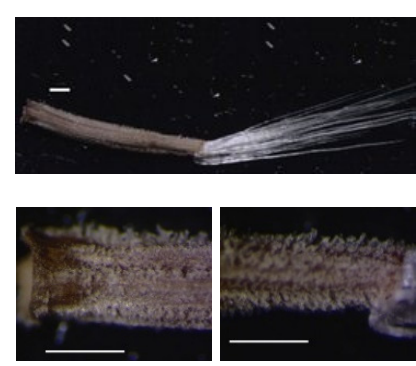

(k)
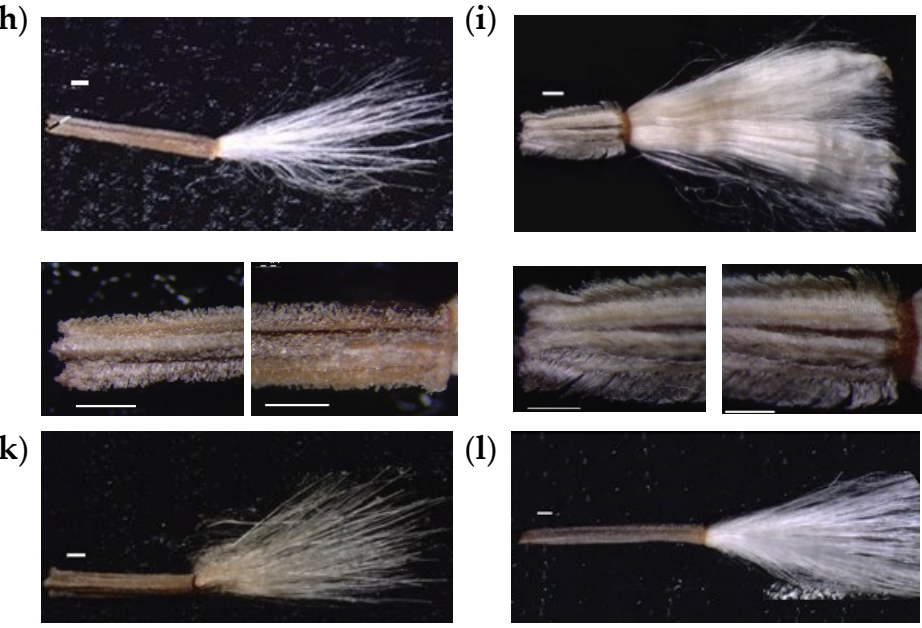

(1)
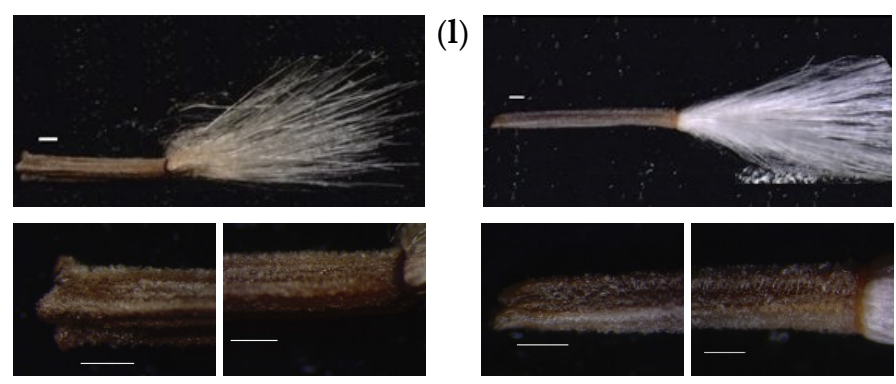

(n)
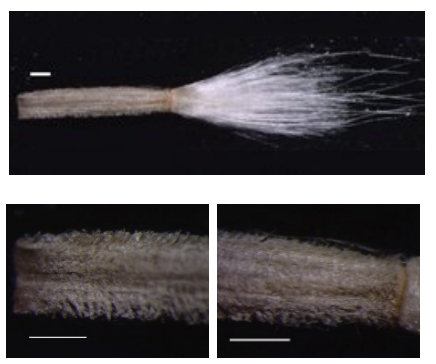

Figure 2. Stereomicrographs of marginal achenes shape (upper), base (lower left) and apex (lower right). (a) Reichardia tingitana, obcolumnar, truncate base and apex. (b-n) Launaea: (b) L. spinosa, subcuneate, truncate base and apex; (c) L. capitata, winged-cylindrical, truncate base and apex; (d) L. intybacea and (e) L. massauensis, beaked-subfusiform, truncate base, rostrate apex; (f) L. nudicaulis, subcuneate, truncate base and apex; (g) L. nudicaulis (specimen 33), subfusiform, truncate base and apex; (h) L. angustifolia subsp. angustifolia, cylindrical, horned base, truncate apex; (i) L. angustifolia subsp. arabica, cylindrical, horned base, truncate apex; (j-1) L. fragilis subsp. fragilis: (j) cylindrical (specimens 129) or (k) columnar (specimens 72) or (1) obcolumnar (specimens 102), horned base, truncate apex; (m,n) L. mucronata: (m) subsp. cassiniana and (n) subsp. mucronata, columnar, truncate base and apex. Scale bar $=0.5 \mathrm{~mm}$. 
(a)
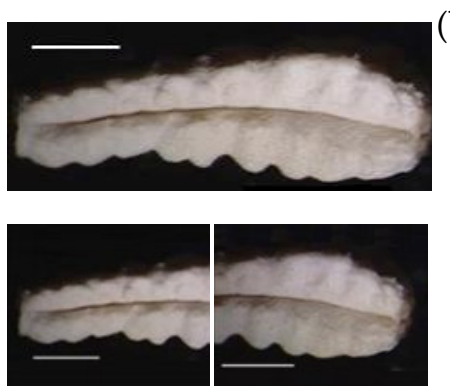

(d)
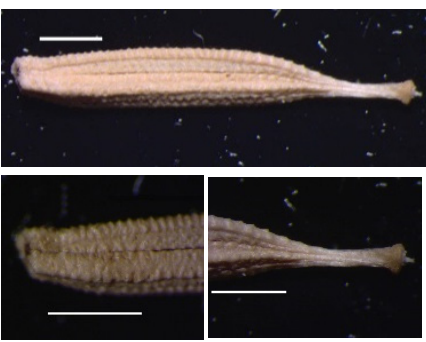

(g)
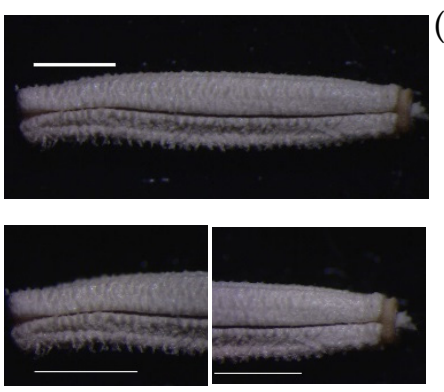

(j)
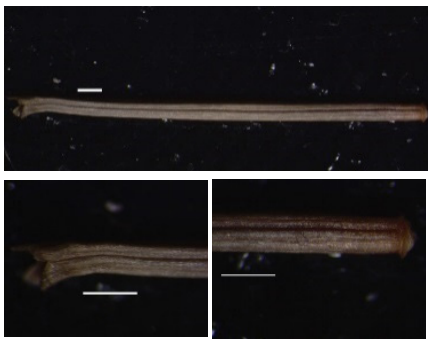

(m)

(e)

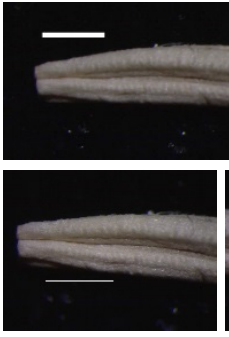

(h)
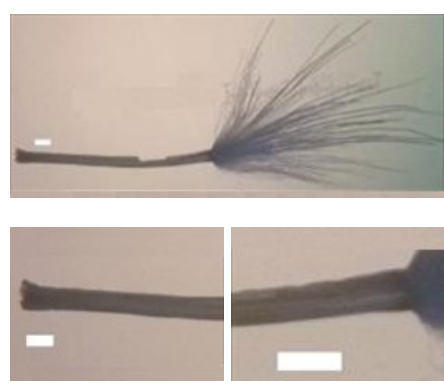

(k)
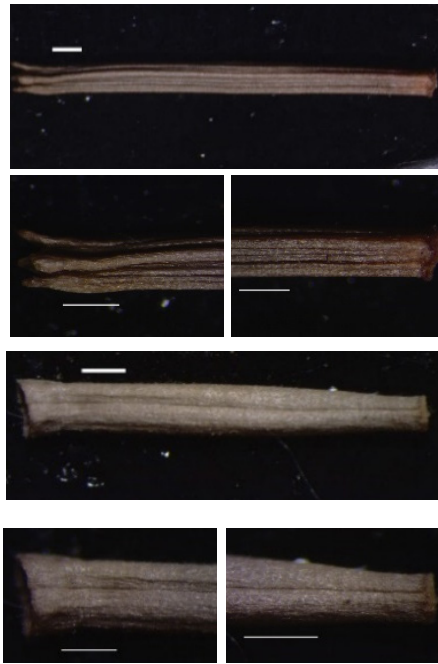
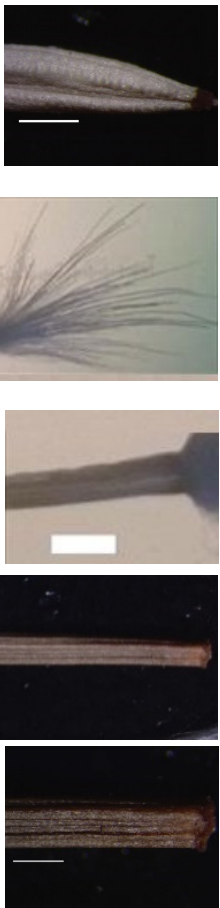

(i)
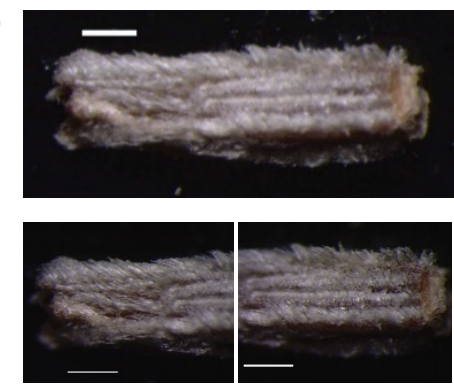

(l)
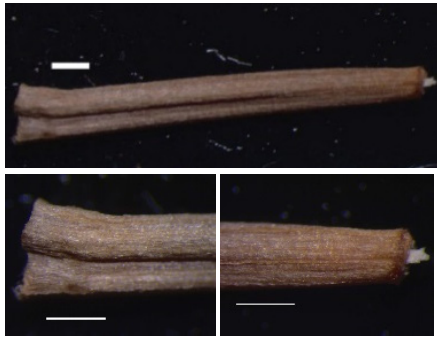

Figure 3. Stereomicrographs of inner achenes shape (upper), truncate base (lower left) and apex (lower right). (a) Reichardia tingitana, columnar, truncate base and apex. (b-m) Launaea: (b) L. spinosa, columnar, truncate base and apex; (c) L. capitata, winged-cylindrical, truncate base and apex; (d) L. intybacea, beaked-cylindrical, truncate base, rostrate apex; (e) L. massauensis, columnar, truncate base, cuspidate apex; (f) L. nudicaulis, cylindrical, truncate base and apex; (g) L. nudicaulis (specimen 33), columnar, truncate base and apex; (h) L. angustifolia subsp. angustifolia, cylindrical, horned base, truncate apex; (i) L. angustifolia subsp. arabica; columnar, horned base, truncate apex; $(\mathbf{j}, \mathbf{k})$ L. fragilis subsp. fragilis: (j) cylindrical (specimens 88 ) or (k) columnar (specimens 102), horned base, truncate apex; (1,m) L. mucronata: (1) subsp. cassiniana, (m) subsp. mucronata, columnar, truncate base, attenuate apex. Scale bar $=0.5 \mathrm{~mm}$. 


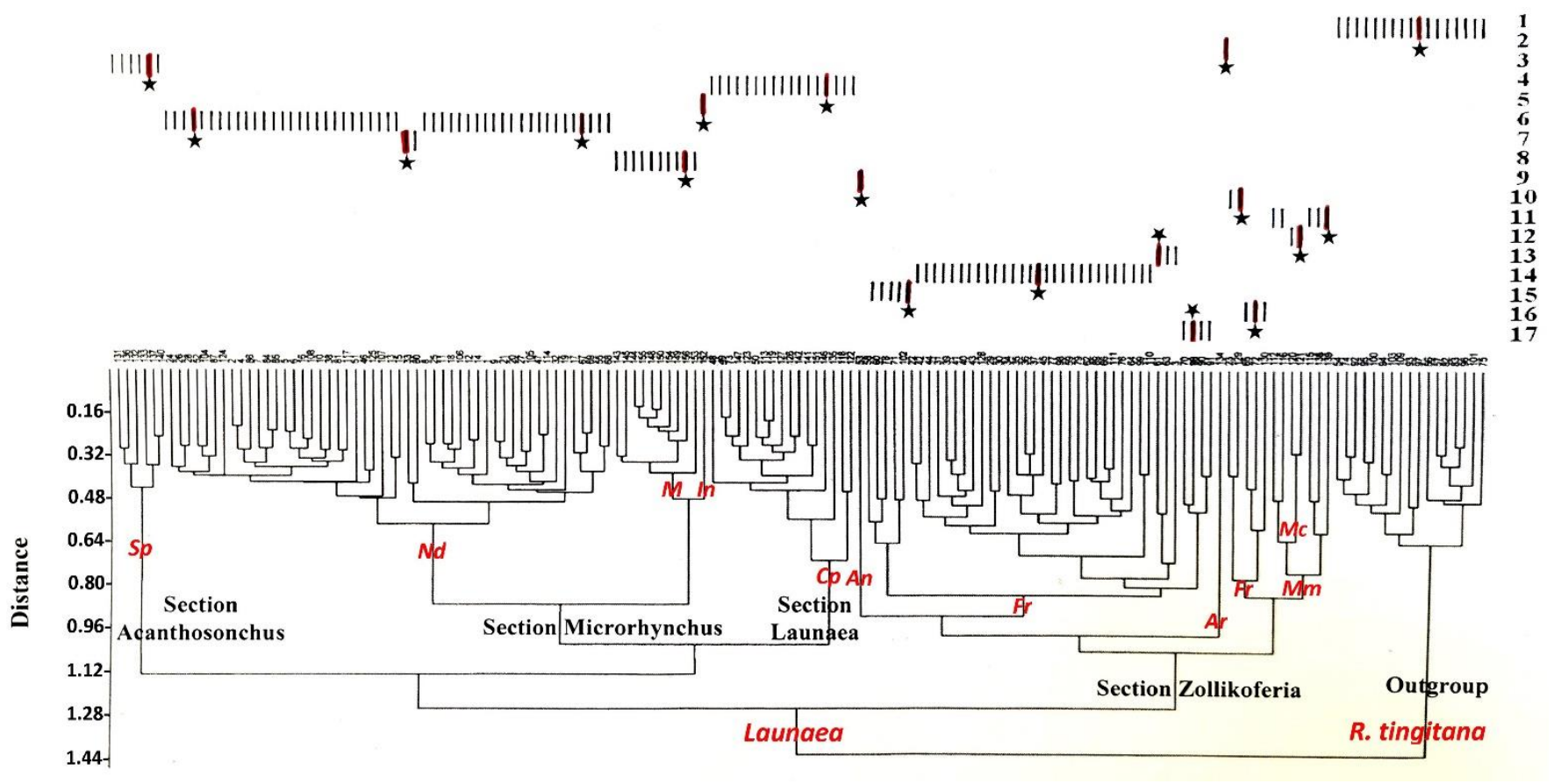

Figure 4. Dendrogram using the UPGMA method of sorting for the 156 specimensof Launaea and Reichardia tingitana. 1, $R$. tingitana; 2, (Ar) L. angustifolia subsp. arabica; 3, (Sp) L. spinosa; 4, (Cp) L. capitata; 5, (In) L. intybacea; 6-7, (Nd) L. nudicaulis; 8, (M) L. massauensis; 9, (An) L. angustifolia subsp. angustifolia; 10, (Fr) L. fragilis subsp. fragilis; 11, (Mm) L. mucronata subsp. mucronata; 12, (Mc) L. mucronata subsp. cassiniana; 10, 13-17, (Fr) L. fragilis subsp. fragilis. Stars indicate the studied specimens for achene and pollen grain micromorphological attributes.

\subsection{Numerical Analysis of Micromorphological Characters (SEM)}

The agglomerative cluster analysis of 17 samples based on 26 achenes (Figures 5 and 6) and pappus characters (Figure 7), and palynological characters (Figure 8) is illustrated in Figure 9. The highest taxonomic distance of the studied groups was 0.830; at this level, both $R$. tingitana and L. angustifolia subsp. arabica were discriminated. At 0.655 dissimilarity level, Launaea sections were distinguished: Acanthosonchus, Launaea, Microrhynchus and Zollikoferia. Both Acanthosonchus and Launaea were represented by L. spinosa and L. capitate, respectively. For section Microrhynchus, two clusters were segregated: "1" and "2" at 0.420 . Cluster " 1 " aggregated both L. intybacea and L. nudicaulis (group 6), while cluster " 2 " grouped L. massauensis and L. nudicaulis (group 7).

Section Zollikoferia was separated into four clusters at 0.50 dissimilarity level. Cluster " 3 " comprised the two subspecies of L. mucronata; cassiniana and mucronata. While, cluster " 4 " aggregated groups 13 and 10 of L. fragilis subsp. fragilis, and the other specimens of the latter subspecies were assembled below cluster " 5 ". Finally, cluster " 6 " isolated L. angustifolia subsp. angustifolia.

The distinction among the seventeen hypothetical groups is performed also by the Principle Coordinate Analysis (PCoA) (Figure 10). The first and second axis explained $31.56 \%$ and $28 \%$ of the variance, respectively, which emphasize a moderate variation for the data. The taxa representing each section were assembled together. The widest range of variation was noticed in section Zollikoferia, especially among the taxa of L. fragilis subsp. fragilis and between the two subspecies of L. angustifolia. 
(a)

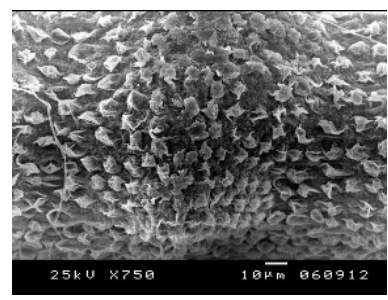

(d)

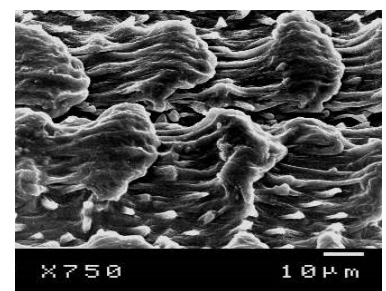

(g)

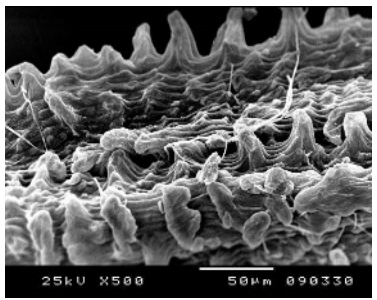

(j)

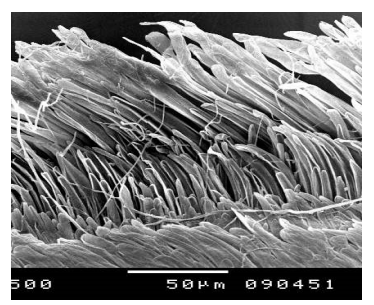

(b)

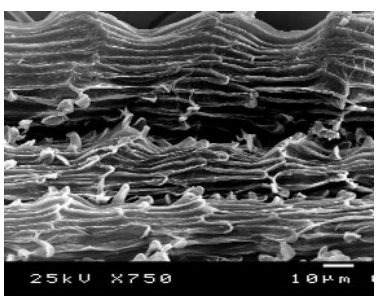

(e)

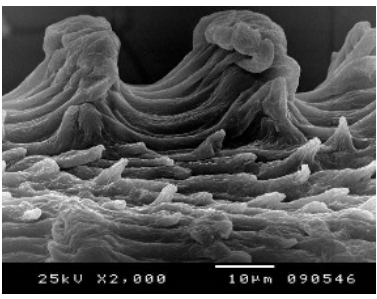

(h)

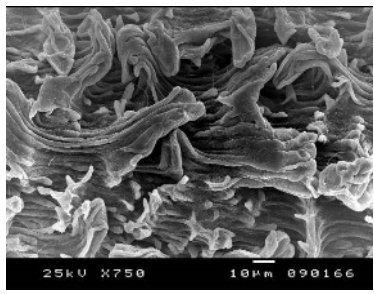

(k)

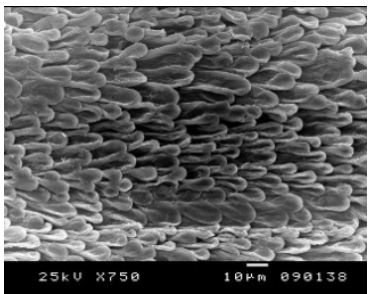

(c)

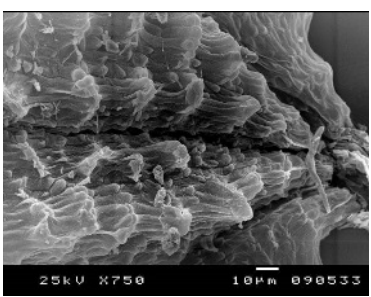

(f)

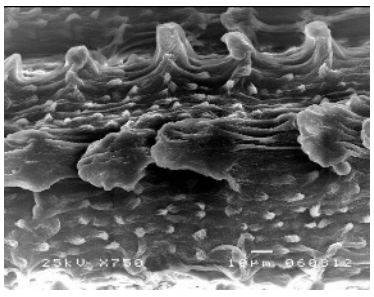

(i)

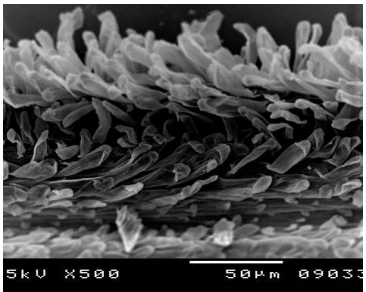

(1)

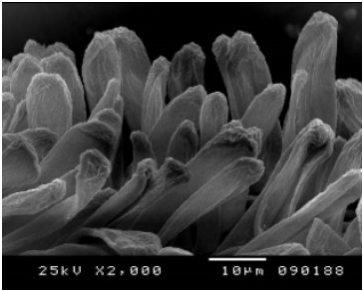

Figure 5. SEM micrographs of marginal achenes. (a) Reichardia tingitana, coarse-verrucate transversely rugose surface. (b-1) Launaea, wrinkled surface: (b) L. spinosa, short squarrose with rounded apex, elongated adjusted epidermal cells with long rounded projections; (c) L. capitata, short squarrose with acute apex, elongated adjusted epidermal cells with short rounded projections; (d) L. intybacea and (e) L. massauensis, long recurved with acute apex, diffused epidermal cells with long acuminate projections; (f,g) L. nudicaulis (group 6), long incurved or recurved with acute apex, nearly adjusted elongated epidermal cells with short acute projections; (h) L. nudicaulis (group 7), long squarrose with acute apex, nearly adjusted elongated epidermal cells with long acuminate projections. (i-1) Launaea, papillose surface: (i) L. angustifolia subsp. angustifolia, long and linear unconnate papillae; (j) L. angustifolia subsp. arabica, long and linear connate papillae forming hyaline wing; (k) L. fragilis subsp. fragilis and (1) L. mucronata subsp. cassiniana, short and clavate papillae.

(a)

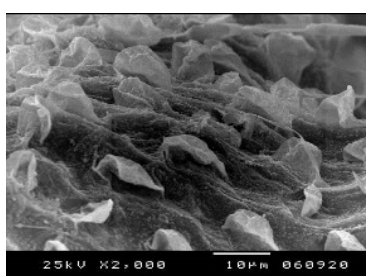

(d)

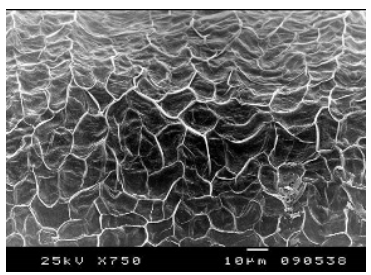

(b)

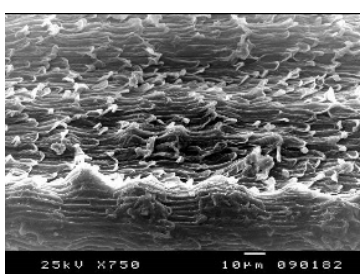

(e)

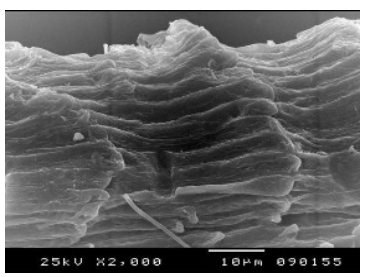

(c)

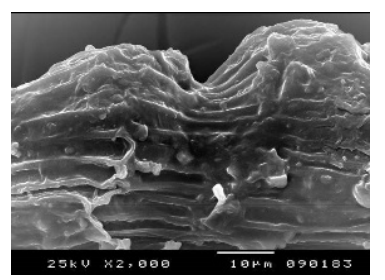

(f)

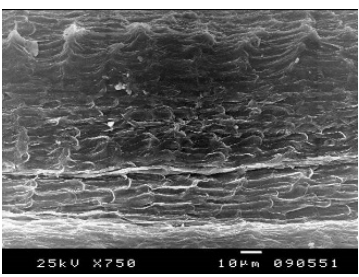

Figure 6. Cont. 
(g)

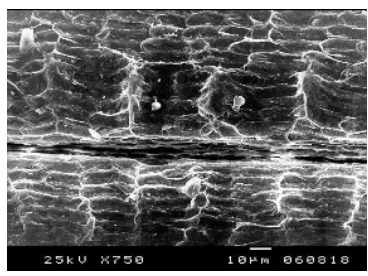

(j)

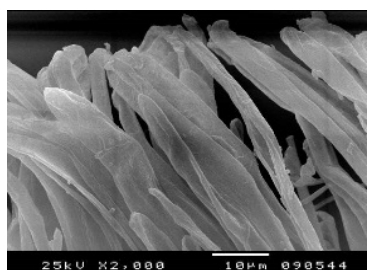

(m)

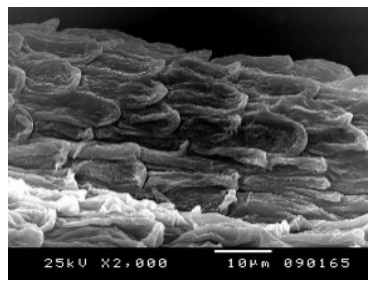

(h)

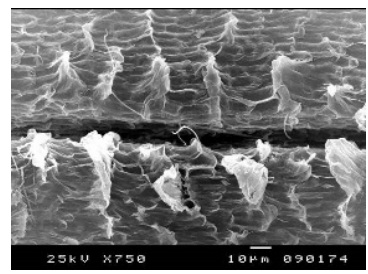

(k)

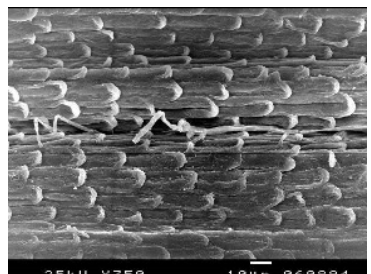

(n)

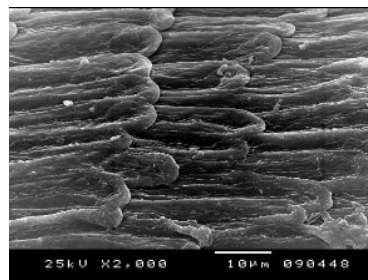

(i)

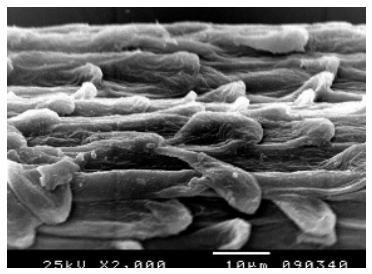

(1)

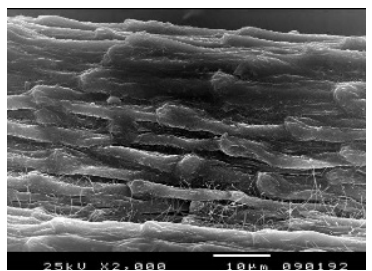

Figure 6. SEM micrographs of inner achenes. Epidermal Cell (EC), End Wall (EW), Anticlinal Wall (AW), Relief of Cell Boundary (RCB), Outer Periclinal Wall (OPW) and Fine Relief of Periclinal Wall (FRPW). (a) Reichardia tingitana, isodiametric EC, obscure EW, AW and RCB, sparsely tuberculate OPW, nearly smooth FRPW. (b-n) Launaea: $(\mathbf{b}, \mathbf{c})$ L. spinosa, elongated nearly adjusted EC, long antrorse projection of EW, raised straight $\mathrm{AW}$, channelled RCB, concave OPW, nearly smooth FRPW; (d) L. capitata, isodiametric EC, EW without projection (at the achene wing), raised straight to irregular AW, raised RCB, concave OPW, nearly smooth FRPW; (e) L. intybacea, elongated adjusted EC, short antrorse projection of EW, raised straight AW, channelled RCB, concave OPW, nearly smooth FRPW; (f) L. massauensis, elongated nearly adjusted EC, EW without projection, raised straight $\mathrm{AW}$, raised RCB, concave OPW, nearly smooth FRPW; (g,h) L. nudicaulis: EW without projection, raised straight $\mathrm{AW}$, raised RCB, concave OPW, nearly smooth FRPW, (g) group 6, elongated adjusted EC, (h) group 7, elongated nearly adjusted EC; (i) L. angustifolia subsp. angustifolia, diffused EC, long antrorse projection of EW, raised straight AW, channelled RCB, flat OPW, striate FRPW; (j) L. angustifolia subsp. arabica, obscure EC, EW, AW and RCB, nearly smooth FRPW, papillose OPW; (k,1) L. fragilis subsp. fragilis, (k) nearly adjusted EC, long antrorse projection of EW, raised straight AW, channelled RCB, flat OPW, nearly smooth FRPW; (1) diffused EC, short antrorse projection of EW, raised straight $\mathrm{AW}$, raised $\mathrm{RCB}$, concave OPW, striate $\mathrm{FRPW} ;(\mathbf{m}, \mathbf{n})$ L. mucronata: elongated adjusted EC, raised straight AW, channelled RCB, flat OPW, striate FRPW, (m) subsp. cassiniana, long antrorse projection of EW, (n) subsp. mucronata, short antrorse projection of EW.

(a)

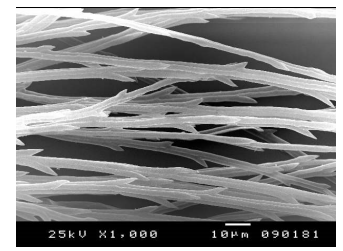

(d)

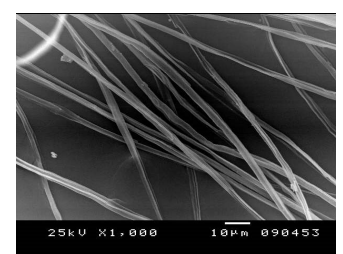

(b)

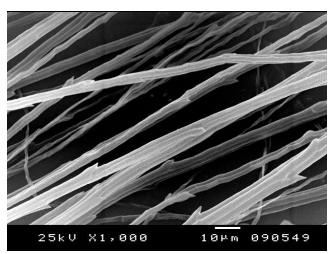

(e)

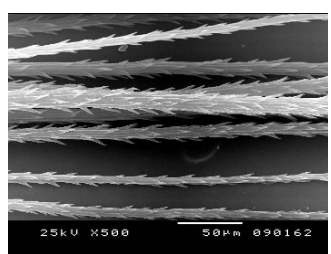

(c)

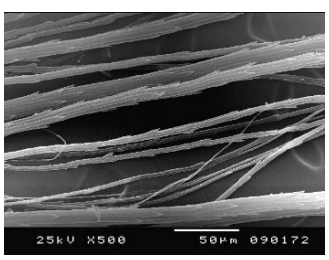

(f)

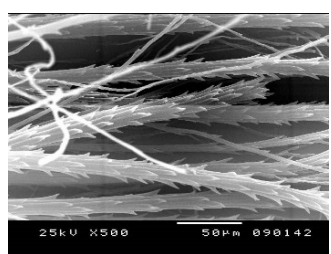

Figure 7. SEM micrographs of pappus type, protuberance density in $150 \mu \mathrm{m}$ and orientation. (a) subhomomorphic setaceous bristles, sparsely, appressed in L. spinosa; (b) dimorphic, sparsely, appressed in L. massauensis; (c) dimorphic, moderate, appressed in L. nudicaulis (group 7); (d) homomorphic of cottony rays, bristles absent in L. angustifolia subsp. arabica; (e,f), high, inclined in L. mucronata: (e), subhomomorphic setaceous bristles in L. mucronata subsp. cassiniana, (f), dimorphic in L. mucronata subsp. mucronata. 
(a)

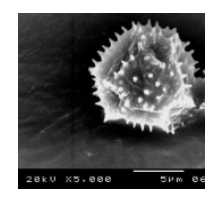

(c)

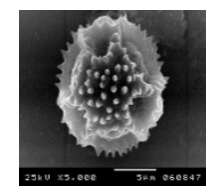

(e)

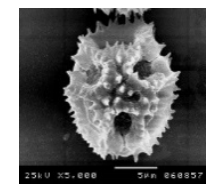

(g)

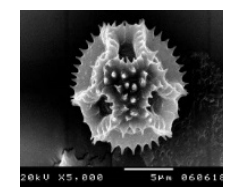

(i)

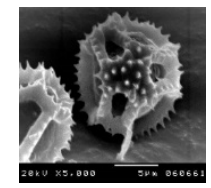

(k)

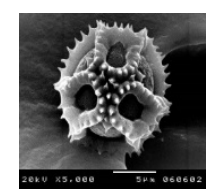

(m)

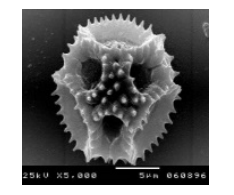

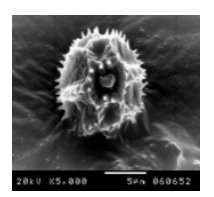
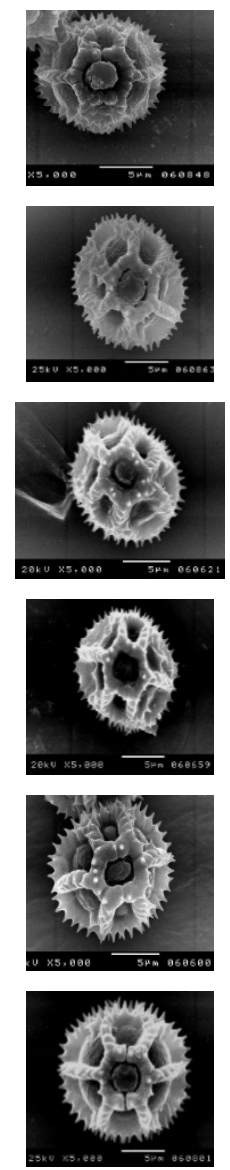
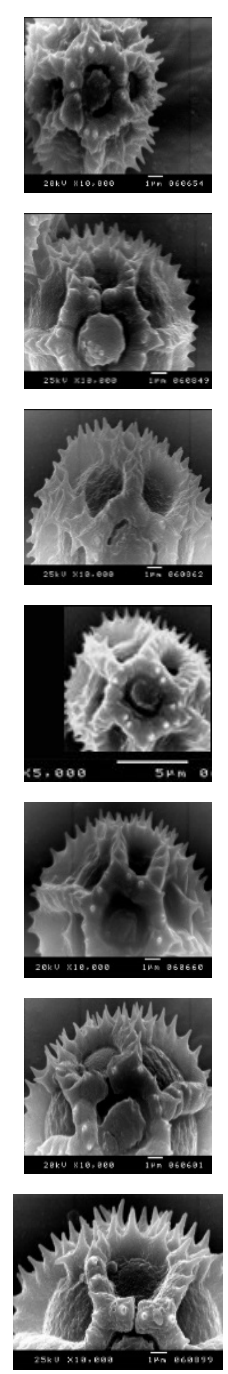

(b)
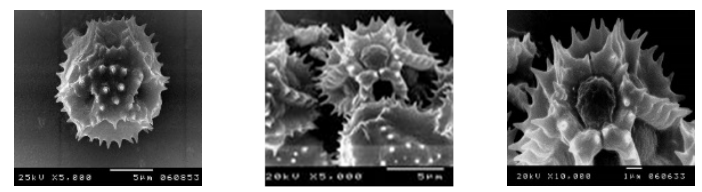

(d)
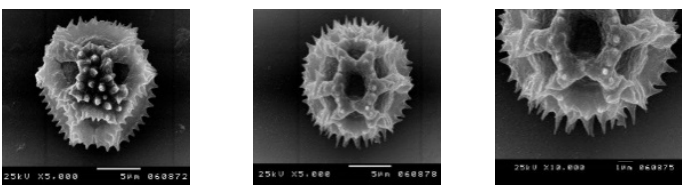

(f)
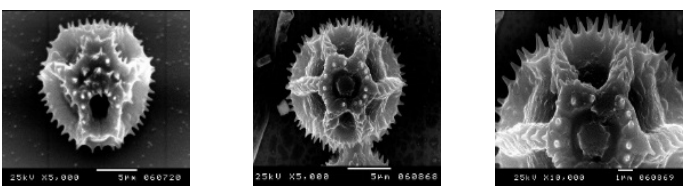

(h)
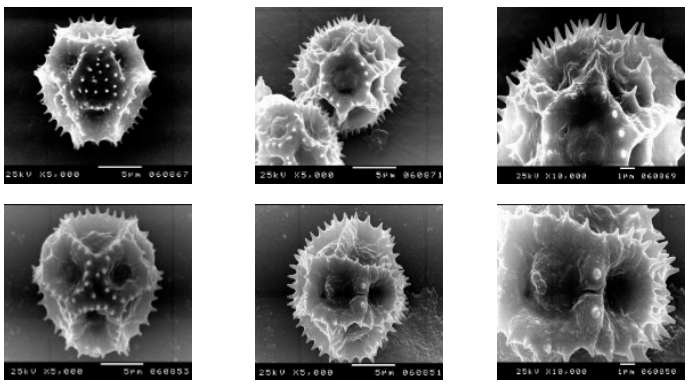

(j)
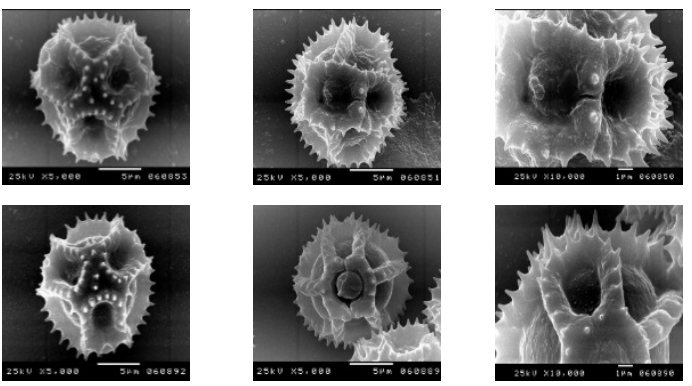

(1)

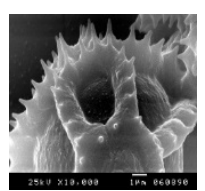

Figure 8. SEM micrographs of pollen grains for polar view (left), equatorial view (middle) and paraporal ridge ornamentation (right) for each taxon. (a) Reichardia tingitana, spiny-granulate. (b-m) Launaea: (b) L. spinosa, spiny; (c) L. capitata, spiny-perforate; (d) L. intybacea and (e) L. massauensis, spiny-perforate; (f,g) L. nudicaulis: (f) group 6, spiny-perforate; (g) group 7, spiny; (h) L. angustifolia subsp. angustifolia, spiny-perforate; (i) L. angustifolia subsp. arabica, spiny; (g-k) L. fragilis subsp. fragilis, (g), group 13, spiny-granulate, (k), group 17, spiny-perforate; (1) L. mucronata subsp. cassiniana, spiny; (m) L. mucronata subsp. mucronata, spiny-perforate. 


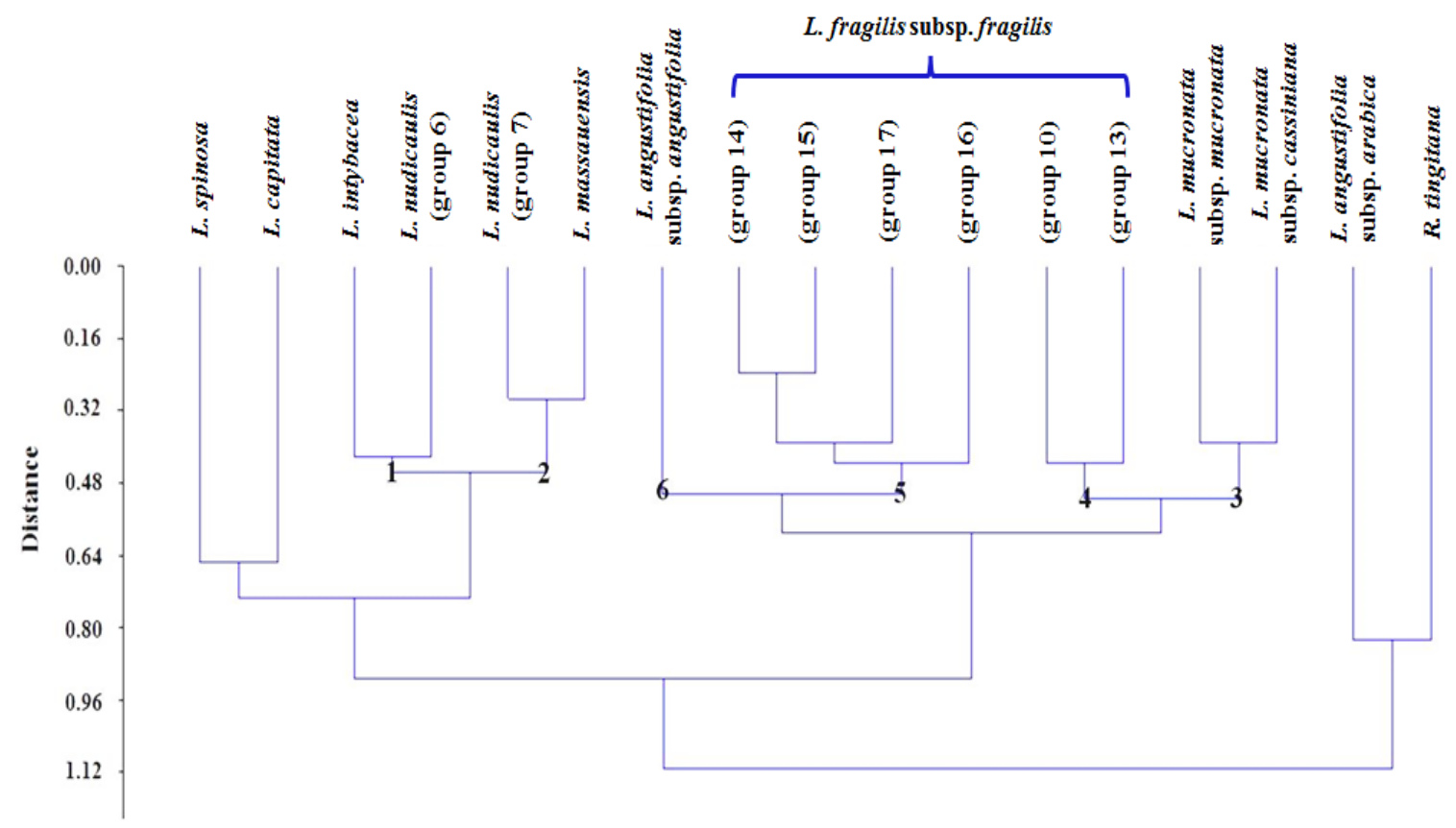

Figure 9. Dendrogram resulted from the UPGMA method of sorting for seventeen samples representing the outgroup Reichardia tingitana and 10 taxa of Launaea based on the achene and the pollen grain micromorphological attributes.

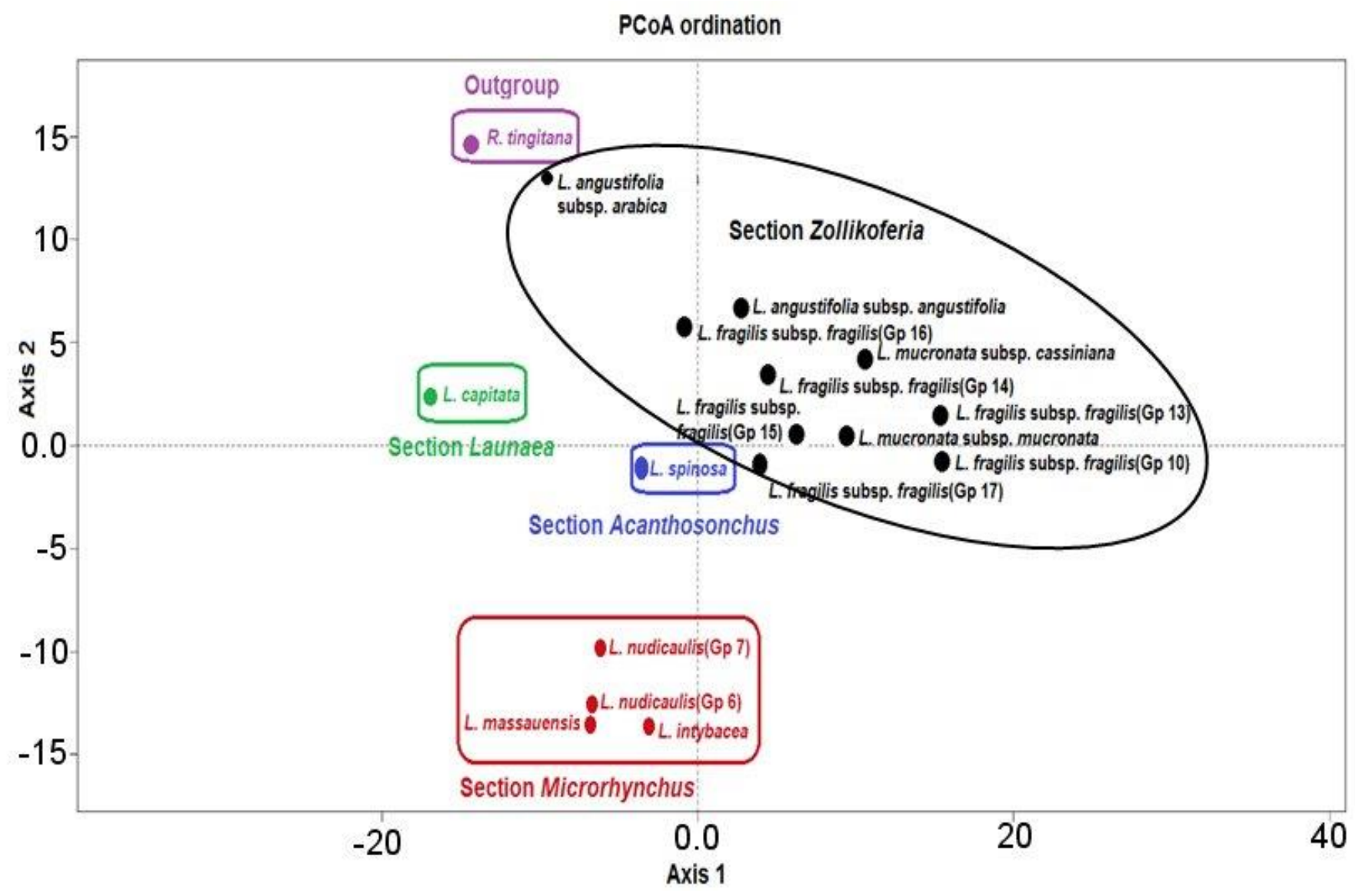

Figure 10. Principal Coordinate Analysis (PCoA) of seventeen samples representing the outgroup Reichardia tingitana and 10 taxa of Launaea based on the achene and the pollen grain micromorphological attributes. 


\section{Discussion}

The current study is the first comprehensive taxonomic study on Launaea in Egypt based on morphological data. R. tingitana was used as an outgroup. The outgroup can be defined as a more distantly related group of taxa that serves as a reference group when determining the phenetic relationships of the in-group [25]. According to Kilian et al. [14], Reichardia and Launaea are the most closely related genera within Hyoseridinae. The detailed characterization of Launaea sections and the species in each one, as well as the taxonomic status for each species, will be summarized in the following part.

\subsection{Section Acanthosonchus}

It is a monospecific section containing L. spinosa, although Zareh et al. [26] have added L. acanthodes (Boiss.) Kuntze as a new record, based on one herbarium specimen (kept in ASTU herbarium) from Wadi Telah in Sinai (7.10.1983). In the current study, this specimen is correctly identified as Lactuca orientalis (Boiss.) Boiss. (Syn. Scariola orientalis Boiss.), which is characterized by spinescent shrub and woolly-floccose white stems of green stripes, as well as the sessile heads with up to 5 florets per capitulum and the achene of 8 main ribs on each face with scabridulous pappus $[4,5,27]$. That is in agreement with Kilian [7], as Lactuca orientalis is confusing and similar to L. acanthodes.

\subsection{Section Launaea}

Osman [28] and Soliman et al. [29] were accepted by only L. capitata in the section. Launaea procumbens (Roxb.) Ramayya and Rajagopal was added as a very rare species by Montasir and Hassib [30], Täckholm [4], Kilian [7] and Boulos [5]. The existence of L. procumbens in Egypt is based on four specimens collected from Wadi Mbaruth (Qoseir), El-Tor (Sinai), Cairo (Pyramids) and Karnak (Luxor) since 1864, 1880, 1902 and 1926, respectively [5,7]. Currently, this species is represented by three sterile specimens collected in 1956 from Wadi Abar (Gebel Ataqa), Wadi Seyal (North Galalah), and Wadi Qiseib (Suez), which are kept in the CAI Herbarium. Therefore, the current study includes only L. capitata in section Launaea.

\subsection{Section Microrhynchus}

Launaeaintybacea, L. massauensis and L. nudicaulis belong to section Microrhynchus.

Launaea intybacea was translocated from Lactuca to Launaea as Launaea fallax or Launaea goraeensis $[4,30]$. It is a very rare species, and it was not recorded in the Egyptian collection of Kilian [7] and Boulos [5]. The present study includes a unique sample deposited in the CAI Herbarium. The sample was collected from Wadi Laseitit (Halayeb Triangle) by Täckholm in 1962.

For Launaea massauensis, the results support involving it with L. intybacea and L. nudicaulis in the same section. This finding corresponds to Kilian [7] for assorting L. massauensis in Microrhynchus instead of Brachyrrhampus DC, as was classified by Boissier [31].

Launaea nudicaulis is a common polymorphic species in Egypt $[4,5,30]$. The investigation of the vegetative and floral characters reveals significant variation resulting from many intermediate forms. The most distinguished characters are the leaf size and shape, capitulescence type, floret dimensions, achene size, color and the degree of wrinkles that decrease in the inward direction. The description coincides with the studies of Amin [6], Kilian [7] and Alavi [32], where the achenes are variable in width, color and degree of wrinkles and achieve a gradual decrease towards the head center.

Two biotypes are distinguished morphologically: biotype 1 (group 6) and biotype 2 (group 7). For biotype 1, the capitulescence is either divaricate or divaricate with a cluster. The marginal achenes are subcuneate of 2.05-3.35 $\times 0.30-0.70 \mathrm{~mm}$, with long incurved or recurved wrinkles of acute apex, and epidermal cells among wrinkles with short acute projections. The inner achenes are cylindrical of 2.05-3.40 $\times 0.25-0.60 \mathrm{~mm}$. They are either compressed or uncompressed with elongated adjusted epidermal cells. The pappus is relatively short, of 5.85 to $9.95 \mathrm{~mm}$, and the bristles reveal four different thicknesses with 
sparse protuberance density. The size of the pollen grains is 13.19-13.99 $\times 14.28-14.92 \mu \mathrm{m}$. The equatorial ridge varies from 4.89 to $5.56 \mu \mathrm{m}$, and the apocolpium diameter from 4.10 to $4.48 \mu \mathrm{m}$. The depth of abporal lacunae ranges from 2.31 to $2.71 \mu \mathrm{m}$, while that of paraporal lacuna is 1.97 to $2.50 \mu \mathrm{m}$. The paraporal ridge ornamentation is either spiny-perforate or spiny-granulate, and the number of spinules on the polar area ranges from 13 to 17.

For biotype 2 , the capitulescence is divaricated. The marginal achenes are subfusiform of 2.40-3.90 × 0.30-0.65 mm, with long squarrose wrinkles of acute apex, and long acuminate projections of the epidermal cells among wrinkles. The inner achenes are compressed and columnar of $2.15-3.30 \times 0.30-0.50 \mathrm{~mm}$, and their epidermal cells are elongated nearly adjusted. The pappus ranges from 7.15 to $10.30 \mathrm{~mm}$, and its bristles possess five different thicknesses of moderate protuberance density. The size of the pollen grains is 11.74-12.34 $\times 11.52-13.12 \mu \mathrm{m}$, the equatorial ridge is from 5.46 to $5.69 \mu \mathrm{m}$, and the apocolpium diameter is from 3.21 to $4.39 \mu \mathrm{m}$. The depth of abporal lacunae varies from 2.29 to $2.40 \mu \mathrm{m}$, whereas the depth of paraporal lacuna ranges from 1.97 to $2.04 \mu \mathrm{m}$. The paraporal ridge ornamentation is spiny, and the number of spinules on the polar area ranges from 13 to 15. The achene macromorphological characters of biotype 2 are congruent with the description of L. procumbens, mentioned by Alavi [32], Kilian [7], Boulos [5] and Qureshi et al. [33], excluding the deciduous homomorphic pappus.

Therefore, the present study suggests two biotypes of L. nudicaulis, one of which shares some macromorphological characters with L. procumbens, such as the subfusiform marginal achenes, the columnar inner achenes and the dimorphic pappus [34]. Determining the taxonomic rank of these biotypes requires freshly collected specimens for L. procumbens and more specialized molecular techniques, such as DNA barcoding, amplified fragment length polymorphism (AFLP), or microsatellites.

\subsection{Section Zollikoferia}

According to the Egyptian taxa, the section contained three subgroups: amal-aminiae, angustifolia and mucronata [7].

In the first subgroup, L. amal-aminiae N.Kilian was recognized by Amin [35] as a distinct and undescribed species. Kilian [7] identified this species according to its leafless flowering stems, slender capitula, and the different indumentum of the achenes. This description was based on five old specimens collected from Sinai, El-Arish, and Wadi Tundebar in Ras Benass (Red Sea) in 1849, 1855 and 1864, respectively. Besides, two specimens were collected from Suez since 1886 and 1908. Through personal communication with Prof. Amal Amin, she clarified that there were two voucher specimens representing this species, kept at the CAI Herbarium. These two specimens were collected from Suakin el Qadim, and from Halayeb Triangle. Nowadays, the two specimens no longer exist at the CAI Herbarium; also Suakin el Qadim became a part of Sudan. As a result, this species was not involved in the present study. The second subgroup, angustifolia, was represented in Egypt by L. angustifolia Muschl. with two subspecies: angustifolia and arabica. Launaea angustifolia subsp. angustifolia was first recorded in Egypt by Zareh et al. [26,36], whereas Kilian [7] declared that the species is restricted to a small area in NW Africa, and it had not been found in Egypt. Our study characterizes the subspecies with its papillose marginal achenes that showed long unconnate papillae in the form of two wings, glabrous inner, and achenes dimorphic pappus. An extensive field survey must be done to address the distribution of this species in Egypt.

Following Muschler [37], Montasir and Hassib [30], Täckholm [4] and Boulos [5], the description of L. angustifolia in Egypt has been applied to the subspecies arabica. Kilian [7] accepted Launaea arabica (Boiss.) H.Lindb. at the subspecies level; L. angustifolia subsp. arabica (Boiss.) N.Kilian. Whereas the current study considered L. arabica at the species level, that is confirmed through the numerical analyses using all types of data, separately and collectively. Marginal and inner achenes of Launaea arabica display long and linear connate papillae (hyaline papillae), and homomorphic pappus of cottony rays. 
The third subgroup mucronata comprises both L. fragilis and L. mucronata. The two species are closely related with relative uniformity and some infraspecific variability [7]. Both taxa were treated as conspecific and were ranked as subspecies or varieties by various authors [32,38,39].

Launaea fragilis is characterized by their auriculated cauline leaves, semiamplexicaul or amplexicaul base, and auricle of either entire or dentate margin. The apices of the outer and middle involucre scales may be acute or acuminate. The inner achenes exhibit conspicuous secondary ribs, and horned base. The pappus is dimorphic with less than 100 setaceous bristles of moderate appressed aristate protuberance, while L. mucronata is specified with auriculated cauline leaves, amplexicaul base, and dissected auricle margin. The apices of the outer and middle involucre scale are acuminate. The inner achenes show ventricose truncate base with either conspicuous or inconspicuous secondary ribs. The pappus is subhomomorphic of setaceous bristles or dimorphic with less than 100 setaceous bristles. The bristles possess inclined aristate protuberance of high density.

The cluster analysis of the micromorphological characters illustrates the separation of groups 10 and 13 of L. fragilis subsp. fragilis with L. mucronata. These groups share some characters, such as the raised straight anticlinal walls of inner achenes, the channelled relief of cell boundary, and the flat outer periclinal walls with striate fine relief. Also, the ratio of polar area to pollen area is less than $40 \%$, and the length spines is more than $1 \mu \mathrm{m}$. Some individuals of L. fragilis share characters with L. mucronata, such as the auriculated leaves, the large capitula, and the ventricose base of the inner achenes. These forms were initiated due to the hybridization between the two species, as they were sympatric in the Nile Delta and the Mediterranean coast in Egypt. In these regions, two cytotypes of L. fragilis were identified, diploid $(2 \mathrm{n}=16)$ and tetraploid $(2 \mathrm{n}=32)[7,29,40]$.

Launaea fragilis subsp. fragilis has demonstrated considerable plasticity and variability in many attributes related to its leaf, capitulum size, number of florets, achene and pappus. These variations were correlated with the ecological amplitude and the wide geographical distribution of the subspecies. Therefore, several names were published at the specific or the infraspecific rank, validly or invalidly, such as L. longiloba (Boiss. and Reut.) Maire, L. resedifolia Druce or L. tenuiloba Muschl. [4,30,41,42].

In Egypt, L. resedifolia was cited as a polymorphic species characterized with linear leaf lobes, the main ribs of the marginal achene are 5 to 6 , and a silky pappus with a length up to $12 \mathrm{~mm}[4,6,32]$. González [43] accepted the name L. fragilis for L. resedifolia and pointed out that the basionym of $L$. resedifolia has belonged to Scorzonera laciniata $L$. L. longiloba was ranked as an ecotype for $L$. fragilis and attributed its vigorous plants to the humidity and favorable conditions by Kilian [7]. Täckholm [4] and Feinburn-Dothan [44] classified L. tenuiloba at the species level. They have described this species by its filiform leaves with entire or dentate lobes, pappus length that is equal to the achene, and its inland distribution. Zareh et al. [26] allocated L. tenuiloba as a subspecies: L. fragilis subsp. tenuiloba (Boiss.) Zareh and Mohamed comb. et stat. nov., based on its various leaf lobes, and the pappus that is longer than the achene.

Our findings discriminate six intermediate forms correlated to the environmental factors without specific features. Consequently, the current study consents L. longiloba, L. tenuiloba and the intermediate forms as ecotypes in L. fragilis subsp. fragilis.

Launaea mucronata Muschl. comprised two subspecies: cassiniana and mucronata [5,7]. They were ranked at the species level by Montasir and Hassib [30] and Täckholm [4]. However, Alavi [32] accepted this species as a variety of L. resedifolia. In light of the studied macro- and micromorphological attributes, the subspecies level is accepted; L. mucronata subsp. cassiniana and L. mucronata subsp. mucronata.

Launaea mucronata subsp. cassiniana has lanceolate rosette leaves, and the capitulum (5.70-5.90 $\times 4.20-5.03 \mathrm{~mm})$ contains about 51 to 56 yellow florets. The compressed inner achenes have inconspicuous secondary ribs, and the epidermal cells have long antrorse projections. The pappus is easily removed and subhomomorphic with the setaceous bristles ranges from 20 to 30 and exhibits three different thicknesses. However, many authors 
have pointed out the presence of homomorphic pappus rather than the subhomomorphic type $[4,5,31,45]$. The pollen grain ornamentation on the paraporal ridge is spiny, and the number of spines on the polar area ranges from 3 to 5 .

Launaea mucronata subsp. mucronata possesses oblong to lanceolate rosette leaves, and the capitulum $(9.64-17.15 \times 4.06-10.26 \mathrm{~mm})$ encloses about 35 to 60 yellow florets. The florets have a green abaxial surface. The inner achenes are uncompressed with conspicuous secondary ribs, and the epidermal cells have short antrorse projections. The pappus is dimorphic and made of up to 40 setaceous bristles with five different thicknesses. Although, Täckholm [4], Amin [6] and Boulos [5] had recorded only 12 to 13 bristles. The pollen grains display a spiny-perforate paraporal ridge, and the number of spines is about 10 to 14 spines on the polar area, the number of spines counted by Osman [28] for the two subspecies agrees with the present study.

The current study proposes a dichotomous indented key for the discrimination and identification often taxa of Launaea based on macro- and micromorphological characters.

1. Spinescent branches; early deciduous cauline and rosette leaves, leaf lobes 4 ; achenes subhomomorphic, inner achene with 5 main ribs .............. L. spinosa

1. Spineless branches; persistent rosette leaves, leaf lobes more than 5; achenes heteromorphic, inner achene with 4 main ribs $\ldots \ldots \ldots \ldots \ldots \ldots \ldots \ldots \ldots$

2. Leaf fragile; marginal achene apex rostrate and beaked $\ldots \ldots \ldots \ldots \ldots \ldots \ldots$

2. Leaf normal; marginal achene apex truncate and not beaked .............. 4

3. Leaf lobe shape ovate; capitulescence divaricate; capitulum width less than $2 \mathrm{~mm}$; inner achene shape columnar and creamy white with apex cuspidate ..... L. massauensis

3. Leaf lobe shape oblong; capitulescence virgate; capitulum width more than $2.5 \mathrm{~mm}$; inner achene shape cylindrical and straw with apex rostrate .......... intybacea

4. Capitulescence glomerate; ligule whitish-yellow; winged achenes, pappus deciduous .......................................... Lapitata

4. Capitulescence diffused, divaricate, or divaricate with cluster; ligule yellow; unwinged achenes, pappus persistent $\ldots \ldots \ldots \ldots \ldots \ldots \ldots \ldots \ldots \ldots \ldots 5$

5. Cauline leaves non-auriculated, rosette leaves runcinate; involucre scales not gradual in length, capitulum shape ellipsoid or lanceoloid; marginal achene shape subcuneate or subfusiform with wrinkled surface, inner achene creamy white ..... L. nudicaulis

5. Cauline leaves auriculated, rosette leaves spathulate; involucre scales gradual in length; capitulum shape obovoid; marginal achene cylindrical or columnar or obcolumnar with papillose surface, inner achene brown $\ldots \ldots \ldots \ldots \ldots \ldots \ldots 6$

6. Rosette leaf lobed, leaf lobe shape ovate; peduncle length less than $1 \mathrm{~cm}$; marginal achene length (2.37-2.5 mm), inner achene length (2.56-2.73 mm), marginal and inner achenes papillose with long and linear connate papillae (hyaline papillae), pappus homomorphic of cottony rays $\ldots \ldots \ldots \ldots \ldots \ldots \ldots \ldots \ldots$ L. arabica

6. Rosette leaf partite or dissected, leaf lobe shape oblong to linear; peduncle length more than $1.5 \mathrm{~cm}$; marginal achene length $(3.20-7.73 \mathrm{~mm})$, inner achene length $(3.47-8.40 \mathrm{~mm})$, marginal achenes only papillose with short and clavate or long and linear unconnate papillae, pappus dimorphic or subhomomorphic of setaceous

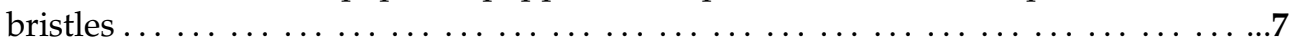

7. Ligule shape linear; marginal achenes with long and linear unconnate papillae; polar area to pollen area ratio $>40 \%$, spinules number on polar area from 16 to $20 \ldots \ldots \ldots$

... angustifolia

7. Ligule shape oblong to linear-lanceolate; marginal achenes with short and clavate papillae; polar area to pollen area ratio $<40 \%$, spinules or spines number on polar area from 3 to $14 \ldots \ldots \ldots \ldots \ldots \ldots \ldots \ldots \ldots \ldots \ldots \ldots \ldots$

8. Auricle margin entire or dentate; inner achene with conspicuous secondary ribs and 4-horned (toothed) base $\ldots \ldots \ldots \ldots \ldots \ldots \ldots \ldots \ldots$. fragilis subsp. fragilis

8. Auricle margin dissected; inner achene with conspicuous or inconspicuous secondary ribs and ventricose truncate base $\ldots \ldots \ldots \ldots \ldots \ldots \ldots \ldots \ldots \ldots \ldots$ 
9. Ligule yellow with green abaxial surface; marginal achene length $(2.95-4.0 \mathrm{~mm})$, marginal achene length to width from 5.1 to 7.0 , inner achene length $(3.40-4.60 \mathrm{~mm})$, inner achene uncompressed with conspicuous secondary ribs, pappus dimorphic; spines number on polar area from 10 to $14 \ldots \ldots \ldots$. . mucronata subsp. mucronata

9. Ligule yellow; marginal achene length $(4.10-4.65 \mathrm{~mm})$, marginal achene length to width from 9.5 to 13 , inner achene length $(5.10-5.60 \mathrm{~mm})$, inner achene compressed with inconspicuous secondary ribs, pappus subhomomorphic of setaceous bristles; spines number on polar area from 3 to $5 \ldots \ldots \ldots$. mucronata subsp. cassiniana

\section{Conclusions}

The combined investigations of the macro-and micromorphological traits are used to revise the classification of ten taxa of Launaea and to assess the inter- and intraspecific variation among taxa. The authors suggest the following points: (1) The taxonomic rank of Launaea angustifolia subsp. arabica must be raised to the species level. It is identified in the present study as Launaea arabica. (2) The elimination of L. acanthodes from the Egyptian flora, as it is identified correctly as Lactuca orientalis (Syn. Scariola orientalis). (3) Two biotypes of L. nudicaulis are distinguished morphologically. One of them shares some macromorphological characters with L. procumbens. Launaea procumbens needs further morphological and molecular investigations using freshly collected materials. (4) Launaea fragilis subsp. fragilis displays considerable plasticity and variability in various characters with intermediate forms, so they are considered ecotypes.

Supplementary Materials: The following are available online at https: / www.mdpi.com/article / 10.3390/taxonomy1030014/s1, Table S1: Classification of the Egyptian Launaea Cass. (1912-2016), Table S2: Taxa of Launaea Cass. and Reichardia tingitana L. Pau collected from 63 sites, Table S3: List of macromorphological characters and their character states recorded for the 156 specimens of Launaea Cass. and Reichardia tingitana L. Pau., Table S4: List of micromorphological characters and their character states recorded for the 156 specimens of Launaea Cass. and Reichardia tingitana L. Pau., Table S5: The characteristic features of seventeen hypothetical groups discriminated macromorphologically. Figure S1: Map of Egypt indicating the localities of the 63 sampling sites (Google Earth Pro 7.1.2.2041). Figure S2: Reichardia tingitana deposited in ALEX Herbarium. Figure S3: Lactuca orientalis (Syn. Scariola orientalis) deposited in ASTU Herbarium. Figure S4: Launaea spinosa deposited in CAI herbaria. Figure S5: Launaea capitata deposited in ALEX herbaria. Figure S6: Launaea intybacea deposited in CAI herbarium. Figure S7: Launaea massauensis deposited in CAI herbarium. Figure S8: Launaea nudicaulis deposited in ALEX herbarium. Figure S9: Launaea angustifolia subsp. angustifolia deposited in ASTU herbarium. Figure S10: Launaea arabica deposited in CAIM herbarium. Figure S11: Launaea fragilis subsp. fragilis deposited in ALEX herbarium. Figure S12: Launaea mucronata subsp. cassiniana deposited in CAIRC herbarium. Figure S13: Launaea mucronata subsp. mucronata deposited in CAIRC herbarium.

Author Contributions: Conceptualization, R.I.M.; methodology, R.I.M. and I.H.N.; validation, R.I.M., S.M.E.-D., S.A.K. and I.H.N.; formal analysis, I.H.N.; investigation, I.H.N.; Funding acquisition: I.H.N.; resources, I.H.N.; data curation, I.H.N.; Visualization: R.I.M. and I.H.N.; writing-original draft preparation, I.H.N.; writing-review and editing, R.I.M., S.M.E.-D., S.A.K. and I.H.N.; supervision, R.I.M., S.M.E.-D. and S.A.K. All authors have read and agreed to the published version of the manuscript.

Funding: This research received no external funding.

Data Availability Statement: The data presented in this study are available in this article and the Supplementary Material.

Acknowledgments: We acknowledge Mahmoud S. Abdelhafez, Ecological Researcher, Elba Protected Area, Natural Conservation Sector, Egyptian Environmental Affairs Agency.Also, we sincerely thank Moatamad M. Tawfik, the technical operator of the Scanning Electron Microscope Unit, Faculty of Science, Alexandria University, Alexandria, Egypt.

Conflicts of Interest: The authors declare no conflict of interest. 


\section{References}

1. Mandel, J.R.; Barker, M.S.; Bayer, R.J.; Dikow, R.B.; Gao, T.G.; Jones, K.E.; Keeley, S.; Kilian, N.; Ma, H.; Siniscalchi, C.M.; et al. The Compositae Tree of Life in the age of phylogenomics. J. Syst. Evol. 2017, 55, 405-410. [CrossRef]

2. Susanna, A.; Baldwin, B.G.; Bayer, R.J.; Bonifacino, J.M.; Garcia-Jacas, N.; Keeley, S.C.; Mandel, J.R.; Ortiz, S.; Robinson, H.; Stuessy, T.F. The classification of the Compositae: A tribute to Vicki Ann Funk (1947-2019). Taxon 2020, 69, 807-814. [CrossRef]

3. Chase, M.W.; Christenhusz, M.J.M.; Fay, M.F.; Byng, J.W.; Judd, W.S.; Soltis, D.E.; Mabberley, D.J.; Sennikov, A.N.; Soltis, P.S.; Stevens, P.F.; et al. An update of the Angiosperm Phylogeny Group classification for the orders and families of flowering plants: APG IV. Bot. J. Linn. Soc. 2016, 181, 1-20. [CrossRef]

4. Täckholm, V. Students' Flora of Egypt, 2nd ed.; Cooperative Printing Company: Cairo, Egypt, 1974.

5. Boulos, L. Flora of Egypt; Al-Hadara Publishing: Cairo, Egypt, 2002; Volume 3.

6. Amin, A.A. A taxonomic revision of the genus Launaea (Compositae.) I. General considerations. Taeckholmia 1978, 9, $111-117$.

7. Kilian, N. Revision of Launaea Cass. (Compositae, Lactuceae, Sonchinae). Englera 1997, 17, 1-478. [CrossRef]

8. Al-Mahrezi, J.A.; Al-Sabahi, J.N.; Akhtar, M.S.; Selim, D.; Weli, A.M. Essential oil composition and antimicrobial screening of Launaea Nudicaulis grown in Oman. Int. J. Pharm. Sci. Res. 2011, 2, 3166-3169.

9. Khidr, Z.A.; Ebad, F.A.; El-Khawaga, H.A. Osmoregulation and antimicrobial activity of two egyptian true xerophytes; Launaea spinosa (Forssk.) and Leptadenia. Egypt. J. Desert Res. 2017, 67, 327-345. [CrossRef]

10. Asif, M.; Saadullah, M.; Yaseen, H.S.; Saleem, M.Y.; Ousaf, H.M.; Khan, I.U.; Yaseen, M.; Shams, M.U. Evaluation of in vivo anti-inflammatory and anti-angiogenic attributes of methanolic extract of Launaea spinosa. Inflammopharmacology 2020, 1, 993-1008. [CrossRef]

11. Emad, F.; Khalafalah, A.K.; El Sayed, M.A.; Mohamed, A.E.H.; Stadler, M.; Helaly, S.E. Three new polyacetylene glycosides (PAGs) from the aerial part of Launaea capitata (Asteraceae) with anti-biofilm activity against Staphylococcus aureus. Fitoterapia 2020, 143, 1-6. [CrossRef]

12. Boulos, L. Flora of Egypt. Checklist; All-Hadara Publishing: Cairo, Egypt, 2009.

13. Thiers, B. Index Herbariorum: A Global Directory of Public Herbaria and Associated Staff. Available online: http://sweetgum. nybg.org/science/ih/ (accessed on 8 January 2021).

14. Kilian, N.; Gemeinholzer, B.; Lack, H.W. Cichorieae. In Systematics, Evolution, and Biogeography of Compositae; Funk, V., Susanna, A., Stuessy, T., Bayer, R., Eds.; International Association for Plant Taxonomy: Vienna, Austria, 2009; pp. $343-383$.

15. Schneider, C.A.; Rasband, W.S.; Eliceiri, K.W. NIH Image to ImageJ: 25 years of image analysis. Nat. Methods 2012, 9, 671-675. [CrossRef]

16. De Vogel, E. Manual of Herbarium Taxonomy; UNESCO: Jakarta, Indonesia, 1987.

17. Simpson, M.G. Plant Systematics; Elsevier Academic Press: London, UK, 2006.

18. Roque, N.; Keil, D.J.; Susanna, A. Illustrated glossary of Compositae. In Systematics, Evolution, and Biogeography of Compositae; Funk, V., Susanna, A., Stuessy, T., Bayer, R., Eds.; International Association for Plant Taxonomy: Vienna, Austria, 2001; pp. 781-806.

19. Hammer, D.A.T.; Ryan, P.D.; Hammer, Ø.; Harper, D.A.T. Past: Paleontological Statistics Software Package for Education and Data Analysis. Palaeontol. Electron. 2001, 4, 1-9.

20. Barthlott, W. Epidermal and seed surface characters of plants: Systematic applicability and some evolutionary aspects. Nord. J. Bot. 1981, 1, 345-355. [CrossRef]

21. Zhang, J.; Boufford, D.E.; Sun, H. Systematic significance of achene morphology in Soroseris, Syncalathium and Parasyncalathium (Asteraceae: Cichorieae). Bot. J. Linn. Soc. 2013, 173, 476-486. [CrossRef]

22. Hussein, H.A.; Eldemerdash, M.M. Comparative Morphology and Surface Microsculpture of Cypsela in Some Taxa of the Asteraceae and Their Taxonomic Significance. Egypt J. Bot. 2017, 56, 409-422. [CrossRef]

23. Punt, W.; Hoen, P.P.; Blackmore, S.; Nilsson, S.; Le Thomas, A. Glossary of pollen and spore terminology. Rev. Palaeobot. Palynol. 2007, 143, 1-81. [CrossRef]

24. Ferreira, E.B.; Cavalcanti, P.P.; Nogueira, D.A. ExpDes: An R Package for ANOVA and Experimental Designs. Appl. Math. 2014, 5, 2952-2958. [CrossRef]

25. Kjer, K.M.; Simon, C.; Yavorskaya, M.; Beutel, R.G. Progress, pitfalls and parallel universes: A history of insect phylogenetics. J. R. Soc. Interface 2016, 13, 1-29. [CrossRef]

26. Zareh, M.M.; Faried, A.M.; Mohamed, M. Revision of Launaea Cass. (Compositae) in Egypt with special references to cypselar diversity. Feddes Repert. 2016, 127, 14-29. [CrossRef]

27. Zareh, M.M. Synopsis of the Family Asteraceae in Egypt. Int. J. Agric. Biol. 2005, 7, 832-844.

28. Osman, A.K.E. Pollen types of the Egyptian species of tribe Lactuceae (subfamily Cichorioideae-Compositae). Acta Bot. Croat 2006, 65, 161-180.

29. Soliman, M.I.; Samaan, L.S.; Ghoniem, G.T.; El-Saied, F.M. Genetic diversity of some Launaea Cass. species in Egypt. Mansoura J. Environ. Sci. 2014, 43, 79-96.

30. Montasir, A.H.; Hassib, M. Illustrated Manual Flora of Egypt; Part 1; Imprimeri Misr, S.A.E.: Cairo, Egypt, 1956.

31. Boissier, E. Flora Orientalis Sive Enumeratio Plantarum in Oriente a Graecia et Aegypto ad Indiae Fines Hucusque Observatarum; Apud H. Georg.: Genevae, Switzerland, 1875; Volume III.

32. Alavi, S.A. Asteraceae. In Flora of Libya; Jafri, S.M.H., El-Gadi, A., Eds.; Al-Faateh University: Trípoli, Libya, 1983. 
33. Qureshi, S.J.; Awan, A.G.; Khan, M.; Bano, S. Taxonomic study of the Genus Launaea L. from Pakistan. J. Biol. Sci. 2002, 2, 315-319.

34. Abou El-Naga, A.Z. Taxonomic and Palynological Studies of Some Species of Compositae in Egypt; Unpublished; El-Mansoura University: Cairo, Egypt, 1990.

35. Amin, A.A. Taxonomic Studies in the Genus Launaea; Unpublished; Cairo University: Cairo, Egypt, 1957.

36. Zareh, M.M.; Faried, A.M.; Mohamed, M. Achene wall anatomy and surface sculpturing of Launaea Cass. (Compositae: Cichorieae) with notes on their systematic significance. Korean J. Plant Taxon. 2016, 46, 187-198. [CrossRef]

37. Muschler, K.; Muschler, R.C. A Manual Flora of Egypt; R. Friedlaender \& sohn: Berlin, Germany, 1912; Volume II.

38. Maire, R. Contributions a l'etude de la flore de l'Afrique du Nord. Bull. Société d'Histoire Nat. L'Afrique Nord 1937, 28, 332-338. [CrossRef]

39. Quezel, P.; Santa, S. Nouvelle flore de l'Algérie et des régions désertiques méridionales; Éditions du Centre National de la Recherche Scientifique: Paris, France, 1963.

40. Amin, A.A. Cytological studies on some Egyptian plants. United Arab Repub. J. Bot. 1973, 16, 501-506.

41. Boissier, E.; Reuter, G.F. Pugillus Plantarum Novarum Africae Borealis Hispaniaeque Australis; Ramboz: Genevae, Switzerland, 1852.

42. Bonnet, E.; Barratte, G. Catalogue Raisonné des Plantes Vasculaires de la Tunisie; Imprimerie Nationale: Paris, France, 1896.

43. González, G.L. Launaea fragilis (Asso) Pau, nombre correcto para L. resedifolia Auct. Plur. Non (L.) Kuntze. An. Jardín Botánico Madr. 1979, 36, 135-138.

44. Feinbrun-Dothan, N. Flora Palaestina, Part 3: Text, Ericaceae to Labiatae; Palestine Academy of Sciences and Humanities: Palestine, Jerusalem, 1977.

45. Kilian, N.; Oberprieler, C.; Vogt, R. Chromosome numbers of North African phanerogams. V. some counts in Launaea (Compositae, Lactuceae). Willdenowia 1995, 25, 273-281. 